\title{
The occurrence and levels of cyanotoxin nodularin from Nodularia spumigena in the alkaline and salty Lake Burdur, Turkey
}

\author{
Fatma SAHINDOKUYUCU KOCASARI,${ }^{1 *}$ Iskender GULLE,${ }^{2}$ Sukru KOCASARI,${ }^{3}$ Selcuk PEKKAYA, ${ }^{4}$ Firdevs MOR ${ }^{1}$ \\ ${ }^{1}$ Department of Pharmacology and Toxicology, Faculty of Veterinary Medicine, University of Mehmet Akif Ersoy, Bahcelievler, \\ 15030 Burdur; ${ }^{2}$ Department of Biology, Faculty of Arts and Science, University of Mehmet Akif Ersoy, Bahcelievler, 15030 Burdur; \\ ${ }^{3}$ The Ministry of Food, Agriculture and Livestock, Burdur; ${ }^{4}$ Veterinary Control and Research Institute, Department of Biochemistry, \\ Ankara, Turkey \\ *Corresponding author: fatmasa@mehmetakif.edu.tr
}

\begin{abstract}
The occurrence of cyanobacteria species Nodularia spumigena and its toxin nodularin were studied in Burdur Lake, a saline alkaline lake with endemic fauna and a Ramsar site of ornithological importance. The water samples were collected from three different locations of Lake Burdur between May and November of 2011. Abundance of Nodularia spumigena and the nodularin levels peaked at the end of July $\left(112,147\right.$ cells $m L^{-1}$ and $\left.4.82 \mu \mathrm{g} \mathrm{L}^{-1}\right)$, coinciding with the highest levels of chlorophyll a (Chl a) (27.15 $\left.\mu \mathrm{g} L^{-1}\right)$ and the water temperature $\left(29^{\circ} \mathrm{C}\right)$. Although fish or other animal deaths were not detected during the episodes, it is concluded that $\mathrm{N}$. spumigena blooming should be monitored in Burdur Lake for the ecosystem and environmental health.
\end{abstract}

Key words: Cyanobacteria bloom, Burdur Lake, Nodularia spumigena, Nodularin, ELISA.

Received: September 2014. Accepted: March 2015.

\section{INTRODUCTION}

Cyanobacteria are a group of prokaryotic organisms that occur worldwide in fresh-, brackish-, and marine waters. Under favorable conditions, cyanobacteria can multiply rapidly to form blooms in water (Kaloudis et al., 2013). According to literature, over a 100 species of cyanobacteria belonging to 40 genera are reported to be toxigenic (Jayatissa et al., 2006). The primary toxin-producing genera include Microcystis, Nodularia, Anabaena, Aphanizomenon, Cylindrospermopsis and Planktothrix (Nasrollahzadeh et al., 2011).

Cyanobacteria are gram-negative bacteria capable of producing a wide range of potent toxins as secondary metabolites, i.e. the cyanotoxins (Van Apeldoorn et al., 2007). Cyanotoxins can be especially detrimental to human and animal health, aquatic habitats and aquaculture enterprises (Kaloudis et al., 2013). Cyanotoxins are very diverse in their chemical structure and toxicity, usually being classified as hepatotoxins, neurotoxins and dermatotoxins according to the toxic effects on animals (De Figueiredo et al., 2004). The most commonly reported cyanotoxins are hepatotoxins and neurotoxins (Al-Jassabi and Khalil, 2006).

The Nodularia spumigena Mertens ex Bornet \& Flahault belonging to Nostocales is a filamentous and dense bloom-forming cyanobacteria species mainly found in slightly saline to brackish waters such as saline inland lakes, coastal lakes, estuaries and seas (Guiry and Guiry,
2014). However, recently nodularin has also been detected in freshwater lakes (Akcaalan et al., 2009; Kaloudis et al., 2013). The N. spumigena blooms are generally toxic, and they usually produce a potent hepatotoxin called nodularin. Structurally, this toxin is a cyclic pentapeptide consisting of D-erythro- $\beta$-methylaspartic acid (D-MeAsp), L-arginine (L-Arg), 3-amino-9-methoxy-2,6,8,-trimethyl10-phenyldeca-4(E), 6(E)-dienoic acid (Adda), D-glutamic acid (D-Glu) and 2-(methylamino)-2-(Z)dehydrobutyric acid (Mdhb). The structure and biological activity of nodularin are similar to cyclic heptapeptides called microcystins the most frequently encountered and best recognized group of toxins produced by freshwater cyanobacteria (Akcaalan et al., 2009; Mazur-Marzec et al., 2009). The characteristic feature of both microcystins and nodularin is the presence of the unusual amino acid Adda which is important for recognition of binding sites responsible for hepatotoxic effects and tumor promoters (Shan et al., 2011).

The hepatotoxicity and carcinogenicity of nodularin is associated with the inhibition of eukaryotic protein phosphatase catalytic subunit types 1 and $2 \mathrm{~A}$. The toxin has been reported to have detrimental effects on numerous organisms within the ecosystem, including invertebrates and fish. The consumption of water containing toxic N. spumigena blooms has led to the death of domestic and native animals by massive liver hemorrhage (Pearson et al., 2010).

Lake Burdur is one of the largest and deepest lakes of Turkey. Lake Burdur is salty $\left(20 \mathrm{~g} \mathrm{~L}^{-1}\right)$ and highly alkaline 
aquatic system (Gülle et al., 2010). However, due to the constant discharge of pollutants into the lake through Burdur city sewage, livestock farming, and industrial wastes for long years, Lake Burdur has undergone rapid eutrophication. The water level of Lake Burdur has decreased about $40 \%$ since 1971 . In addition, two occurrences of cyanobacterial blooms in 2000 and 2007 caused by $N$. spumigena were reported, leading to fish mortality (Anonymous, 2000; Yıldırım et al., 2008). Earlier studies prior to 2000 event regarding the lake's water quality of Lake Burdur reported no case of blooms and also no information about the presence of cyanotoxins (Arcak and Altındağ, 2000; Girgin et al., 2004; Gülle et al., 2010). Thus, the present study is the first survey on the presence, levels of nodularin in Lake Burdur which has a cyanobacteria-dominated system.

The aim of this study was to investigate water quality parameters, $N$. spumigena densities, and nodularin concentrations in samples from Lake Burdur between May 2011 and November 2011.

\section{METHODS}

\section{Description of study area}

Lake Burdur is located at the Lake District Region in

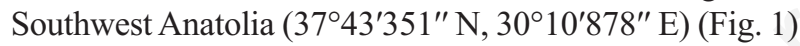
and has a surface area of $147 \mathrm{~km}^{2}$ and a catchment area of $4120 \mathrm{~km}^{2}$. One of the deepest lakes in Turkey, average depth in Lake Burdur is $30 \mathrm{~m}$, while $61 \mathrm{~m}$ in its deepest point. Lake Burdur has high alkaline ( $\mathrm{pH}$ 9.1) and brackish water character $\left(20 \mathrm{~g} \mathrm{~L}^{-1}\right)$ of $\mathrm{Na}-\mathrm{Mg}-(\mathrm{Cl})-\mathrm{SO}_{4}-\mathrm{HCO}_{3}$ type and $\mathrm{C}_{5} \mathrm{~S}_{5}$ class. It is unavailable for domestic, drinking, industrial or agricultural uses as it has also very high water hardness. A species of killifish Aphanius sureyanus and a copepod species Arctodiaptomus burduricus are endemic species to the lake. It is one of the lakes in Central Anatolia that does not freeze during winter, therefore Lake Burdur has great a ornithological importance due to great numbers of wintering birds, and being the main wintering site for the globally threatened duck Oxyura leucocephala in Turkey. Burdur Lake is a Ramsar Site since 1993 and Wild Life Reserve (Yarar and Magnin, 1997; Girgin et al., 2004; Gülle et al., 2010).

Samples of water from Lake Burdur were collected from May to November in 2011. Sampling stations are described in Fig. 1. Station I at 37 $33^{\circ} 351^{\prime \prime}$ N, 30 $30^{\circ} 10^{\prime} 878^{\prime \prime}$ E, station II at $37^{\circ} 46^{\prime} 849^{\prime \prime} \mathrm{N}, 30^{\circ} 16^{\prime} 256^{\prime \prime} \mathrm{E}$, and station III at $37^{\circ} 44^{\prime} 517^{\prime \prime} \mathrm{N}, 30^{\circ} 13^{\prime} 981^{\prime \prime} \mathrm{E}$.

\section{Sampling and measurements}

Samples were collected at a depth of $0.5-1 \mathrm{~m}$ in $1.7 \mathrm{~L}$ Nansen bottles, pre-washed with $\mathrm{HCl}$ and distilled water (APHA-AWWA-WEF, 1999). Temperature, $\mathrm{pH}$, electrical conductivity, salinity (YSI $63 \mathrm{pH} / \mathrm{SCT}$ meter), dissolved oxygen (YSI 550A), turbidity (WTW Turb 355IR) and transparency (Secchi disc depth) were measured in situ

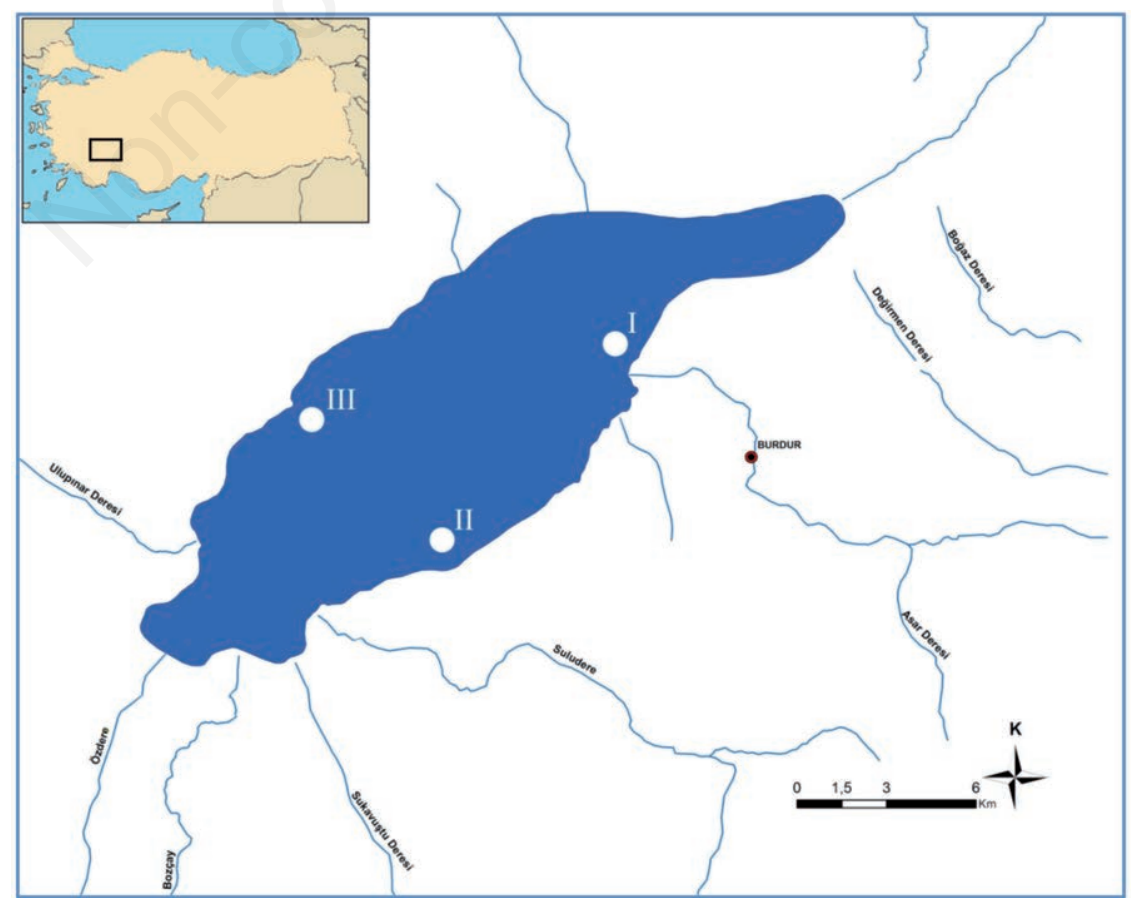

Fig. 1. Burdur Lake and sampling sites. 
every sampling station. Also, total phosphorus (as $\mathrm{P}_{-} \mathrm{PO}_{4}$ ) and nitrate $\left(\mathrm{N}-\mathrm{NO}_{3}\right)$ determined according to the procedure described by Merck Spectroquant ${ }^{\circledR}$ Cell-test kit. The chlorophyll $a$ (Chl- $a$ ) concentration was determined spectrophotometrically. Cyanobacteria cells were filtered through a filter (1.2 $\mu \mathrm{m}$ pore sized glass fiber filter paper), and the pigments were extracted in the $90 \%$ acetone solution and analyzed according to APHA-AWWA-WEF (1999).

The method of Komárek et al. (2003) was used for the identification of phytoplankton morphospecies. Phytoplankton samples $(500 \mathrm{~mL})$ were fixed in Lugol's solution. The $N$. spumigena density was determined under a binocular microscope via Sedgwick-Rafter counting chambers. Shortly samples were concentrated to $10 \mathrm{~mL}$ by counting filaments added, and then average number of $N$. spumigena cell of randomly selected 20 filaments were used to express the cell number per milliliter (cells $\mathrm{mL}^{-1}$ ). This procedure was repeated several times with different filaments and an arithmetic mean was established (APHA-AWWA-WEF, 1999).

Nodularin analysis was performed using an Enzyme Linked Immuno Sorbent Assay (ELISA). Extraction of samples was conducted according to the instructions of the ELISA kit (Abraxis LLC, 522015, Warminster, PA, USA). One-hundred $\mu \mathrm{L}$ of seawater sample treatment solution were added to the water samples ( $1 \mathrm{~mL}$ each), which then stirred for $1 \mathrm{~min}$ and incubated for $30 \mathrm{~min}$ at room temperature. All standards, control and lake water samples were run in duplicate. One-hundred $\mu \mathrm{L}$ standard solutions control and test samples were added to each well. Then, $50 \mu \mathrm{L}$ of enzyme conjugate and $50 \mu \mathrm{L}$ antibody solutions were added to each well, mixed thoroughly and incubated for 90 $\mathrm{min}$ at room temperature. At the end of incubation, the wells were washed three times with $250 \mu \mathrm{L}$ of washing buffer. After, $150 \mu \mathrm{L}$ colour solution was added to each well, mixed thoroughly and incubated for $20 \mathrm{~min}$ at the room temperature. After the incubation, $100 \mu \mathrm{L}$ of the stop solution was added to each well and mixed. The absorbance was measured at $450 \mathrm{~nm}$ by an ELISA plate reader (ELX800; Bio-Tek Instruments, Winooski, VT, USA).

The extracellular nodularin levels in samples were evaluated using the MS Excel spreadsheet prepared by Abraxis. The levels of nodularin standards used were 0 , $0.15,0.40,1,2$ and $5 \mu \mathrm{g} \mathrm{L}^{-1}$. According to the test preparation record, the lower detection limit was $0.10 \mu \mathrm{g} \mathrm{L}^{-1}$.

\section{RESULTS}

The water quality parameters determined during the study were presented in Tab. 1. Moderately dissolved oxygen concentration was observed in surface waters of the lake having an alkaline $(\mathrm{pH}>9)$ and hyposaline $(19.99 \mathrm{~g}$ $\mathrm{L}^{-1}$ ) character (Tab. 1). According to the findings (Tab. 1), Carlson's Trophic State Index (TSI) values were calculated from Secchi's disc transparency $(1.63 \mathrm{~m}), \mathrm{Chl} a$ $\left(14.33 \mu \mathrm{g} \mathrm{L}^{-1}\right)$ and total phosphorus $\left(0.19 \mathrm{mg} \mathrm{L}^{-1}\right)$ from the measurements and found as 53, 57 and 80, respectively. Based on these values, the trophic state of the lake is determined as eutrophic according to OECD criteria and TSI values (Wetzel, 2001).

The highest $N$. spumigena cell density (St 2, mean $72.810^{3}$ cells $\mathrm{mL}^{-1}$ ) coincides with the maximum water temperature and turbidity $\left(28^{\circ} \mathrm{C}\right.$ and $\left.18.75 \mathrm{NTU}\right)$ values of Lake Burdur during mid-summer (on July $30^{\text {th }}$ ), when the cyanobacteria proliferation became visible (Fig. 2). However, the maximal $\mathrm{Chl} a\left(45.11 \mu \mathrm{g} \mathrm{L}^{-1}\right)$, turbidity (18.75 NTU) and minimum transparency $(0.3 \mathrm{~m})$ levels were found in St I.

The nodularin concentrations are found in our study to be ranging between 0.30 and $4.82 \mu \mathrm{g} \mathrm{L}$ L $^{-1}$ (Fig. 3) and generally correlated with the water temperature, $\mathrm{Chl} a$ concentration and the $N$. spumigena density (Tab. 1; Figs. 4 and 5). The N. spumigena densities and the nodularin concentrations regression relationship were found to be high $\left(\mathrm{R}^{2}=0.88\right)$ (Fig. 6).

\section{DISCUSSION}

The cyanobacterial blooms are common and formed mostly by Microcystis, Anabaena, Planktothrix, Aphanizomenon and Nostoc species in fresh waters, while in marine and brackish environments, toxic blooms are less common and formed by N. spumigena (Mazur-Marzec et

Tab. 1. Water quality parameters of Lake Burdur determined during May-November 2011 period (mean $\pm S D, n=12)$.

\begin{tabular}{lccc} 
Parameters & Mean \pm SI & Min. & Max. \\
Temperature $\left({ }^{\circ} \mathrm{C}\right)$ & $21.6 \pm 4.6$ & 9.9 & 29 \\
$\mathrm{pH}$ & $9.04 \pm 0.04$ & 8.97 & 9.12 \\
\hline Dissolved oxygen $\left(\mathrm{mg} \mathrm{L}^{-1}\right)$ & $7.59 \pm 1.40$ & 4.78 & 10.6 \\
Conductivity $\left(\mathrm{mS} \mathrm{cm}^{-1}\right)$ & $32.13 \pm 0.46$ & 31.12 & 32.93 \\
\hline $\mathrm{TDS}\left(\mathrm{g} \mathrm{L}^{-1}\right)$ & $22.29 \pm 0.39$ & 21.69 & 23.05 \\
Salinity $\left(\mathrm{g} \mathrm{L}^{-1}\right)$ & $19.99 \pm 0.27$ & 19.20 & 20.40 \\
\hline $\mathrm{N}^{-N}\left(\mathrm{mg} \mathrm{L}^{-1}\right)$ & - & - & $<0.1$ \\
\hline
\end{tabular}

$T D S$, total dissolved solids. 
al., 2006). N. spumigena blooms have been reported from brackish waters of Australia (Heresztyn and Nicholson, 1997; McGregor et al., 2012), America (Beutel et al., 2001), Africa (Harding et al., 1995), Baltic Sea (Kononen et al., 1993; Mazur and Pliński, 2003; Henriksen, 2005; Mazur-Marzec et al., 2006, 2009, 2013; Suikkanen et al., 2007, Kankaanpää et al., 2009), and Caspian Sea (Nasrollahzadeh et al., 2011). The mass occurrence of $N$. spumigena in Lake Burdur was recorded in 2000 for the first time and second for the brackish waters of Turkey (Gülle et al., 2010), the species now the most dominant cyanobacteria species in Lake Burdur. The first brackish water N. spumigena bloom record (July 1996) was from Bafa Lake (Kazanc1 et al., 2008).
The seasonal occurrence of $N$. spumigena blooms varries according to the literature. Heresztyn and Nicholson (1997) reported the $N$. spumigena blooms during the summer/autumn of 1994-1995 in lakes Alexandrina and Albert (South East Australia). However, McGregor et al. (2012) observed later N. spumigena blooms between September and November of 2008 in Carbrook Cable Ski Lake, South East Australia. Similarly, Nasrollahzadeh et al. (2011) described the $N$. spumigena bloom in Caspian Sea as starting from middle of summer with a maximum in early of autumn. On the other hand, in the Gulf of Gdańsk (Baltic Sea), the intensive N. spumigena blooms were observed in summer (late June-early July in 2001 and in late July-early August in 2002) (Mazur and Pliński,

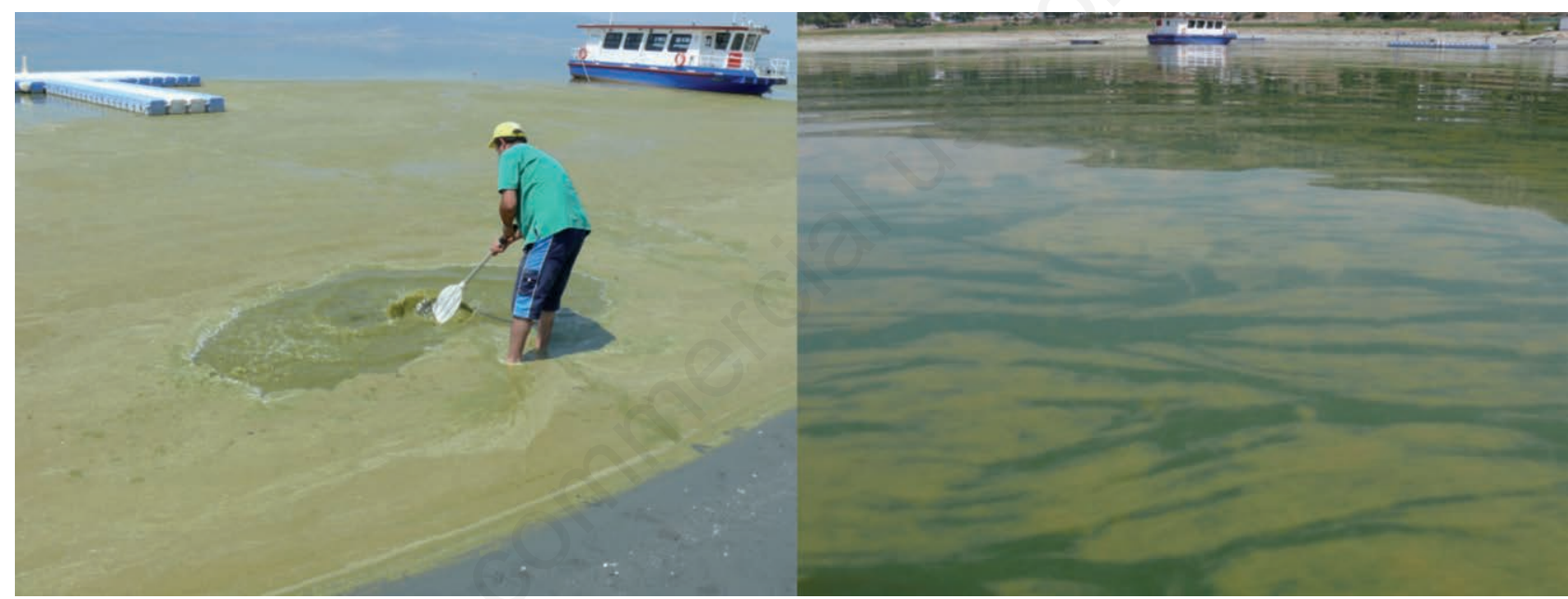

Fig. 2. Accumulation of N. spumigena filaments near the lake shore and surface during the blooms (2011.07.30 St. II). (Courtesy I. Gülle).

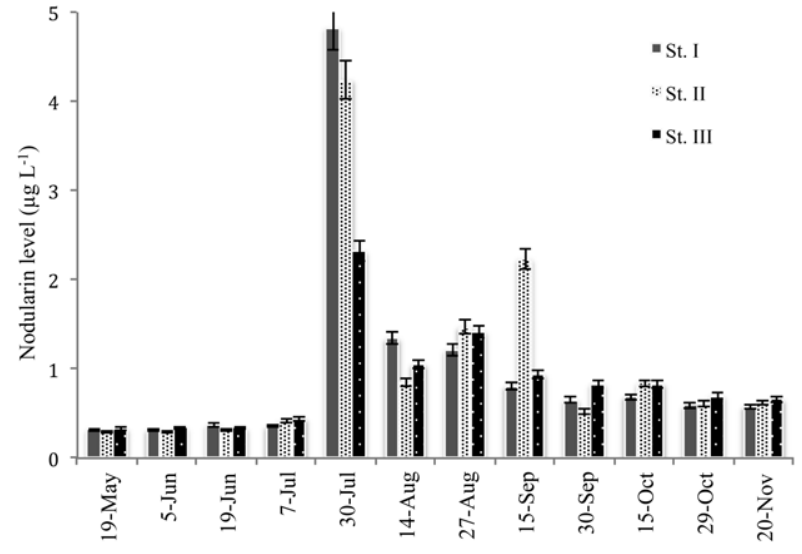

Fig. 3. Nodularin levels $\left(\mu \mathrm{g} \mathrm{L}^{-1}\right)$ in sampling stations of Lake Burdur.

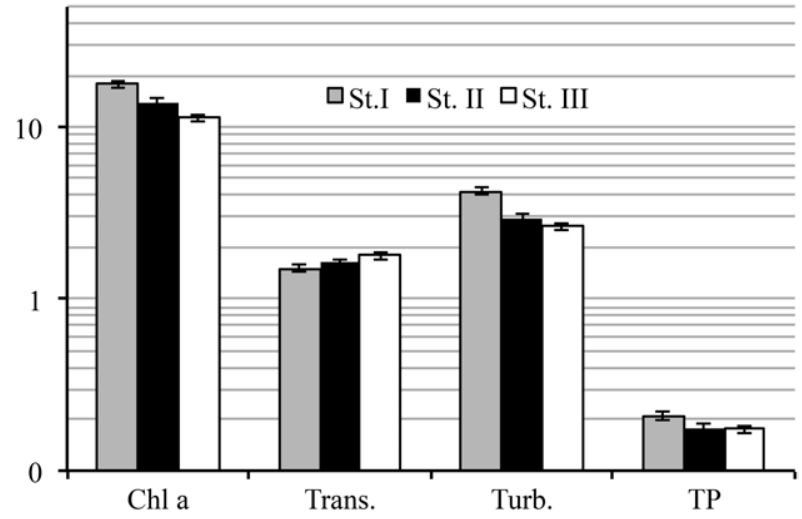

Fig. 4. The average Chl $a\left(\mu \mathrm{g} \mathrm{L}^{-1}\right)$, transparency (m), turbidity (NTU) and total phosphorus $\left(\mathrm{mg} \mathrm{L}^{-1}\right)$ measurements in sampling stations of Lake Burdur. 
2003). Our results (late July-early August) were similar to that of Mazur and Pliński (2003). It is considered that the seasonality of the blooms could be related with environmental factors.

The several environmental factors have been considered to enhance the blooms of cyanobacteria (Ballot et al., 2003). The growth of $N$. spumigena is influenced by temperature, salinity, light irradiance, low N:P ratio (Mazur and Pliński, 2003; Henriksen, 2005). Holland et al. (2013) reported that the Nodularia blooms occurred in waters with salinity between 9-20 and the water temperature above $20^{\circ} \mathrm{C}$. Several study results (Mazur and Pliński, 2003; Mazur-Marzec et al., 2006) demonstrated that growth of the $N$. spumigena is strongly temperature-dependent and is optimal at $25-28^{\circ} \mathrm{C}$. In our study, during the bloom, water temperature was $25-28^{\circ} \mathrm{C}$ and salinity was 19.83-20.05 $\mathrm{g} \mathrm{L}^{-1}$. Salinity has been drastically increased (by around 50\%, 13-14 to $20 \mathrm{~g} \mathrm{~L}^{-1}$ ) due to drying of the lake. However, this increase is not considered as an important factor since the blooms have been observed in lower salinities. The nitrogen limitation, a condition when the ratio of dissolved inorganic nitrogen (DIN) to dissolved phosphorus (filterable reactive phosphorus, FRP) is less than about 10:1, is assumed to be another factor and $N$. spumigena blooms reportedly occur when DIN:FRP is $<5: 1$ (Holland et al., 2013). As a general condition encountered in salty lakes (Jelison, and Melack 2001 ), nitrogen limitation is a natural phenomenon in

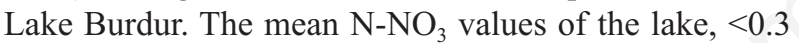
$\mathrm{mg} \mathrm{L}^{-1}\left(<0.1 \mathrm{mg} \mathrm{L}^{-1}\right.$ in our study) (Anonymous, 2013), are much lower than the minimal eutrophication limits for the fresh water systems. The increased levels of P mainly resulting from domestic pollutants during 2000s have lowered down the N:P ratio (Gülle et al., 2010; Yıldırım et al., 2008).

The maximum density of $N$. spumigena in our study

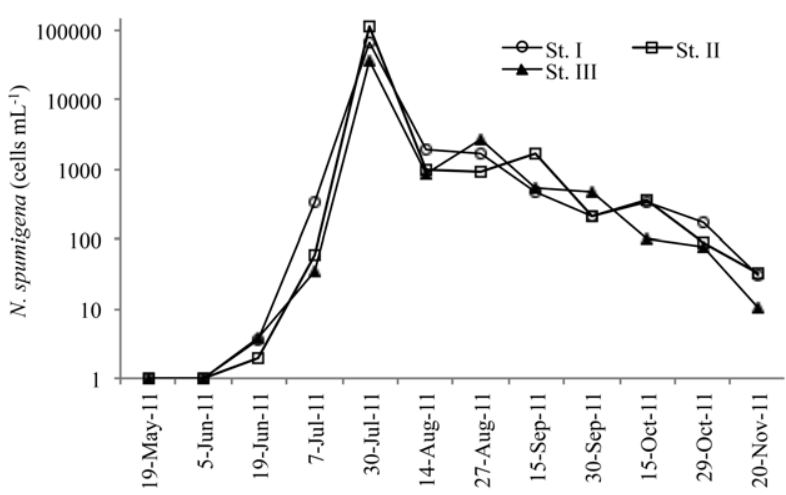

Fig. 5. Spatial and temporal change of $N$. spumigena density (cells $\mathrm{mL}^{-1}$ ) in sampling stations of Lake Burdur. ranged from $37.610^{3}$ to $112.110^{3}$ cells $\mathrm{mL}^{-1}$ (mean 72.8 $10^{3}$ cells $\mathrm{mL}^{-1}$ ). The intensity of the bloom can be evaluated as mild compared with the figures of other studied lakes, Carbrook Cable Ski Lake for instance having a cell density between $164.510^{3}$ and $605.210^{3}$ cells $\mathrm{mL}^{-1}$ (McGregor et al., 2012). However, the intensity of the blooms are observed to fluctuate largely among the years (Kankaaanpää et al., 2009; Nasrollahzadeh et al., 2011).

As mentioned, Chl- $a$ concentrations are used as an important indicator for microalgae biomass production in water ecosystems. In this study, there is a strong correlation between the Chl- $a$ concentrations and the density of the $N$. spumigena observed to be the dominant phytoplankton during the bloom period.

The present study is the first study to document nodularin presence in a brackish-saline lake in Turkey. The nodularin concentrations in Lake Burdur were measured between 0.30 and $4.82 \mu \mathrm{g} \mathrm{L}^{-1}$. Our results are within the range of the results obtained from different studies performed in Baltic Sea in which the spectrum of the results is much wider (Kononen et al., 1993; Mazur and Pliński, 2003; Henriksen, 2005). In this study, the correlation between the nodularin concentration and the $N$. spumigena density was found to be high $\left(R^{2}=0.88\right)$ and close to the findings of Mazur-Marzec et al. (2013) in Baltic Sea $\left(R^{2}=0.895\right)$, while relatively lower than that of Henriksen (2005) $\left(R^{2}=0.95\right)$.

Nodularin is a potent hepatotoxin in humans and animals (Pearson et al., 2010). The $\mathrm{LD}_{50}$ of nodularin is approximately $50 \mu \mathrm{g} \mathrm{kg}^{-1}$ body weight in mice when given intra-peritoneally (Carmichael et al., 1988). With such a low $\mathrm{LD}_{50}$, nodularin is one of the most potent natural toxins. At doses below this concentration, nodularin may act as a carcinogen via the initiation and promotion of liver cell division (Pearson et al., 2010). Several cases of death and poisoning of aquatic and terrestrial animals (sheep,

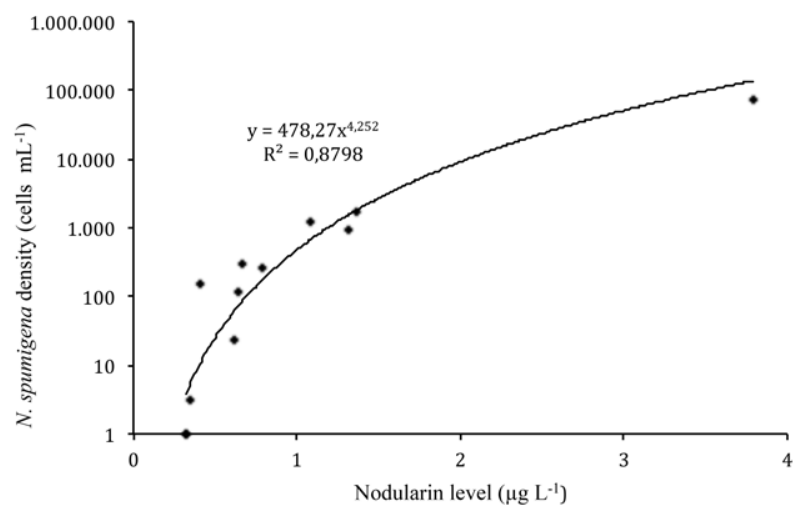

Fig. 6. The relationship between $N$. spumigena density and nodularin concentration. 
lambs, horses, dogs, pigs and prawns) following contact with $N$. spumigena were recorded (Edler et al., 1985; Nehring, 1993; Steffensen et al., 1999; Kankaanpää et al., 2005). So far there have been no confirmed reports of human fatalities attributable to the $N$. spumigena. However, people who have bathed in an area with a cyanobacteria bloom have suffered from allergic reactions, skin irritation and indigestion-related illnesses (Mazur and Pliński, 2003).

The World Health Organization has provided a provisional guideline value of $1 \mu \mathrm{g} \mathrm{L}^{-1}$ microcystins for drinking water (WHO, 1998). Although microcystins concentrations more than $1 \mu \mathrm{g} \mathrm{L}^{-1}$ in drinking water is regarded as unsafe by WHO, there is no any value set by WHO for nodularin concentration.

One of the two endemic organisms of Lake Burdur is a copepod, A. burduricus, the dominant zooplankton of the lake. Regarding the interaction between copepods and $N$. spumigena, direct grazing effect or toxic effect have been vigorously debated (Koski et al., 1999, 2002; Sellner et al., 1996). During our study, no mortality in endemic fish $A$. sureyanus and the aquatic birds were observed after the blooms as well as during the blooms. This can be rough evidence about absence of toxic effect of $N$. spumigena blooms even during the maximum nodularin levels of the study period (up to a $4.82 \mu \mathrm{g} \mathrm{L}^{-1}$ ).

\section{CONCLUSIONS}

The Lake Burdur is a large saline lake and an important Ramsar site. Even if blooms of $N$. spumigena have been recorded, very few information is available on cyanobacteria and their toxicity in the lake. The results of this study could be important in terms of presence of cyanobacteria and cyanotoxins in Lake Burdur (from May to November 2011), and could contribute to the knowledge on cyanobacterial blooms in brackish-saline lakes.

The effects of the Nodularia blooms on the endemic fauna of Burdur Lake and the food chain should be studied in the future studies. The negative trend of the changes in and around of the lake is likely to remain in the future, thus more severe blooms may be expected. Therefore, how the drying process of Lake Burdur and its possible consequences as increased salinity and increase in trophic level affects the Nodularia proliferation could be studied in detail to understand the nature of recent blooms in the lake.

\section{ACKNOWLEDGMENTS}

This study was supported by the Mehmet Akif Ersoy University Scientific Research Fund (Project No: 0130NAP-11). The authors thank the anonymous reviewers for their valuable contributions and suggestions to the manuscript, and Dr. Umit Kebapci (Mehmet Akif Ersoy University, Burdur) for correcting English of the text.

\section{REFERENCES}

Akcaalan R, Mazur Marzec H, Zalewska A, Albay M, 2009. Phenotypic and toxicological characterization of toxic Nodularia spumigena from a freshwater lake in Turkey. Harmful Algae 8:273-278.

Al-Jassabi S, Khalil AM, 2006. Initial report on identification and toxicity of Microcystin in King Talal Reservior, Jordan. Lake Reserv. Res. Manage. 11:125-129.

Anonymous, 2000. Nodularia spumigena (Cyanobacteria) blooms in Burdur Lake. Limnological Report, Suleyman Demirel University Egirdir Fisheries Faculty.

Anonymous, 2013. Burdur Lake. Republic of Turkey Ministry of Forestry and Water Affairs, General Directorate of Nature Conservation and National Parks, Department of Sensitive Areas, Wetland Division; Burdur Lake Subbasin Biodiversity Research Subproject.

APHA-AWWA-WEF, 1999. Standard methods for the examination of water and wastewater. $20^{\text {th }}$ ed. American Public Health Association, Washington.

Arcak S, Altındağ A, 2000. Water quality and ecologycal properties of Burdur Lake, p. 81-90. Proceedings of the Int. Symp. on Desertification, Konya, Turkey.

Ballot A, Pflugmacher S, Wiegand C, Kotut K, Krienitz L, 2003. Cyanobacterial toxins in Lake Baringo, Kenya. Limnologica 33:2-9.

Beutel MW, Horne AJ, Roth JC, Barratt NJ, 2001. Limnological effects of anthropogenic desiccation of a large, saline lake, Walker Lake, Nevada. Hydrobiologia 466:91-105.

Carmichael WW, Eschedor JT, Patterson GML, Moore RE, 1988. Toxicity and partial structure a hepatotoxic peptide produced by the cyanobacterium Nodularia spumigena Mertens emend. L575 from New Zealand. Appl. Environ. Microb. 54:2257-2263.

De Figueiredo DR, Azeiteiro UM, Esteves SM, Goncalves, FJM, Pereira MJ, 2004. Microcystin-producing blooms-a serious global public health issue. Ecotox. Environ. Safe. 59:151-163.

Edler L, Ferno S, Lind MG, Lundberg R, Nilsson PO, 1985. Mortality of dogs associated with a bloom of the cyanobacterium Nodularia spumigena in the Baltic Sea, Ophelia 24:103-109.

Girgin S, Kazanc1 N, Dügel M, 2004. On the limnology of deep and saline Lake Burdur in Turkey. Acta Hydro. Hydrob. 32:189-200.

Guiry MD, Guiry GM, 2014. AlgaeBase. World-wide electronic publication, National University of Ireland, Galway. Accessed on: 11 February 2014. Available from: http://www.algaebase.org

Gülle I, Turna II, Güçlü, SS, Gülle P, Güçlü Z, 2010. Zooplankton seasonal abundance and vertical distribution of highly alkaline Lake Burdur, Turkey. Turk. J. Fish. Aquat. Sci. 10:245-254.

Harding WR, Rowe N, Wessels JC, Beattie KA, Cood GA, 1995. Death of a dog attributed to the cyanobacterial (bluegreen algal) hepatotoxin nodularin in South Africa. J. S. Afr. Vet. Assoc. 66:256-259.

Henriksen P, 2005. Estimating nodularin content of cyanobacterial blooms from abundance of Nodularia spumigena and its characteristic pigments - a case study from Baltic entrance area. Harmful Algae 4:167-178. 
Heresztyn T, Nicholson BC, 1997. Nodularin concentrations in lakes Alexandrina and Albert, South Australia, during a bloom of the cyanobacterium (blue-green alga) Nodularia spumigena and degradation of the toxin. Environ. Toxic. Water 12:273-282.

Holland D, Woodland R, Cook P, Clarke R, Herrod A, 2013. Ecological impacts of a Nodularia bloom on nitrogen dynamics in food webs and seagrass beds. Available from: http:/www.gippslandlakes.net.au/wp-content/uploads/ 2012/08/Ecological-impacts- of-Nodularia-final.pdf

Jayatissa LP, Silva EIL, McElhiney J, Lawton LA, 2006. Occurrence of toxigenic cyanobacterial blooms in freshwaters of Sri Lanka. Syst. Appl. Microbiol. 29:156-164.

Jelison R, Melack JM, 2001. Nitrogen limitation and particulate elemental ratios of seston in hypersaline Mono Lake, California, U.S.A. Hydrobiologia 466:1-12.

Kankaanpää H, Holliday J, Schroder H, Goddard TJ, von Fister R, Carmichael WW, 2005. Cyanobacteria and prawn farming in northern New South Wales, Australia - a case study on cyanobacteria diversity and hepatotoxin bioaccumulation. Toxicol. Appl. Pharm. 203:243-256.

Kankaanpää H, Sjovall O, Huttunen M, Olin M, Karlsson K, Hyvärinen K, Sneitz L, Härkönen J, Sipiä VO, Meriluoto JAO, 2009. Production and sedimentation of peptide toxins nodularin-R and microcystin-LR in the northern Baltic Sea. Environ. Pollut. 157:1301-1309.

Kaloudis T, Zervou SK, Tsimeli K, Triantis TM, Fotiou T, Hiskia A, 2013. Determination of microcystins and nodularin (cyanobacterial toxins) in water by LC-MS/MS. Monitoring of Lake Marathonas, a water reservoir of Athens, Greece. J. Hazard. Mater. 263P:105-115.

Kazanc1 N, Girgin S, Dügel M, 2008. Research on the limnology of Bafa Lake in South-Western Turkey and climate change impacts. Rev. Hydrobiol. 2:207-223.

Komárek J, Komárková J, Kling H, 2003. Filamentous Cyanobacteria, p. 117-196. In: J.D. Wehr and R.G. Sheath (eds.), Freshwater algae of the United States. Academic Press, Amsterdam.

Kononen K, Sivonen K, Lehtimaki J, 1993. Toxicity of phytoplankton blooms in the Gulf Finland and Gulf of Bothnia, Baltic Sea, p. 269-274. In: T.J. Smayda and Y. Shimizu (eds.), Toxic phytoplankton blooms in the sea. Elsevier.

Koski M, Engstrom J, Viitasalo M, 1999. Reproduction and survival of the calanoid copepod Eurytemora affinis fed with toxic and non-toxic cyanobacteria. Mar. Ecol. Prog. Ser. 186:87-197.

Koski M, Schmidt K, Engstrom-Ost J, Viitasalo M, Jodonasdottir S, Repka S, Sivonen K, 2002. Calanoid copepods feed and produce eggs in the presence of toxic cyanobacteria Nodularia spumigena. Limnol. Oceanogr. 47:878-885.

Mazur H, Pliński M, 2003. Nodularia spumigena blooms and the occurrence of hepatotoxin in the Gulf of Gdańsk. Oceanologia 45:305-316.

Mazur-Marzec H, Krezel A, Kobos J, Pliński M, 2006. Toxic Nodularia spumigena blooms in the coastal waters of the Gulf of Gdan'sk: ten-year survey. Oceanologia 48:255-273, Mazur-Marzec H, Sutryk K, Kobos J, Hebel A, Hohlfed N,
Blaszczyk A, Toruńska A, Kaczkowska MJ, Lysiak-Pastuszak E, Kraśniewski W, Jasser I, 2013. Occurrence of cyanobacteria and cyanotoxin in the Southern Baltic proper. Filamentous cyanobacteria versus single-celled picocyanobacteria. Hydrobiologia 701:235-252.

Mazur-Marzec H, Torunska A, Blonska MJ, Moskot M. Plinski M, Jakobkiewicz-Banecka J, Wegrzyn G, 2009. Biodegradation of nodularin and effects of the toxin on bacterial isolates from The Gulf of Gdańsk. Water Res. 43:2801-2810.

McGregor GB, Stewart I, Sendall BC, Sadler R, Reardon K, Carter S, Wruck D, Wickramasinghe W, 2012. First report of a toxic Nodularia spumigena (Nostocales/cyanobacteria) bloom in sub-tropical Australia. I. Phycological and public health investigations. Int. J. Environ. Res. Public Health 9:2396-2411.

Nasrollahzadeh HS, Makhlough A, Pourgholam R, Vahedi F, Qanqermeh A, Foong SY, 2011. The study of Nodularia spumigena bloom event in the southern Caspian Sea. Appl. Ecol. Environ. Res. 9: 141-155.

Nehring S, 1993. Mortality of dogs associated with a mass development of Nodularia spumigena (cyanophyceae) in a brackish lake at the German North Sea coast. J. Plankton Res. 15:867-872.

Pearson L, Mihali T, Moffitt M, Kellmann R, Neilan B, 2010. On the chemistry, toxicology and genetics of the cyanobacterial toxins, microcystin, nodularin, saxitoxin and cylindrospermposin. Mar. Drugs 8:1650-1680.

Sellner KG, Olson MM, Olli K, 1996. Copepod interactions with toxic and nontoxic cyanobacteria from the Gulf of Finland. Phycologia 35:177-182.

Shan Y, Shi X, Dou A, Zou C, He H, Yang Q, Zhao S, Lu X, Xu $\mathrm{G}, 2011$. A fully automated system with on-line micro solidphase extraction combined with capillary liquid chromatography-tandem mass spectrometry for high throughput analysis of microcystins and nodularin- $\mathrm{R}$ in tap water and lake water. J. Chromatogr. A 1218:1743-1748.

Steffensen D, Burch M, Nicholson B, Drikas M, Baker P, 1999. Management of toxic blue-green algae (cyanobacteria) in Australia. Environ. Toxicol. 14:183-195.

Suikkanen S, Laamanen M, Huttunen M, 2007. Long-term changes in summer phytoplankton communities of the open northern Baltic Sea. Estuar. Coast. Shelf S. 71:580-592.

Van Apeldoorn ME, Van Egmond HP, Speijers GJA, Bakker GJI, 2007. Toxins of cyanobacteria. Mol. Nutr. Food Res. 51:7-60.

Wetzel RG, 2001. Limnology: lakes and river ecosystems. 3. Academic Press: 1006 pp.

WHO, 1998. Cyanobacterial toxins: microcystin-LR. Guidelines for drinking water quality. Health Criteria and other supporting information. World Health Organization, Geneva.

Yarar M, Magnin G, 1997. [Türkiye'nin önemli kuş alanları]. [Book in Turkish]. Doğal Hayatı Koruma Derneği, İstanbul: $313 \mathrm{pp}$

Yıldırım MZ, Gülle I, Kebapçı U, Küçük F, 2008. Faunal diversity of Lake Burdur, and its vulnerability. Proceedings of the $3^{\text {th }}$ Int. Symp. of Ecologists of Montenegro, Podgorica. Natura Montenegrina 7:393-400. 